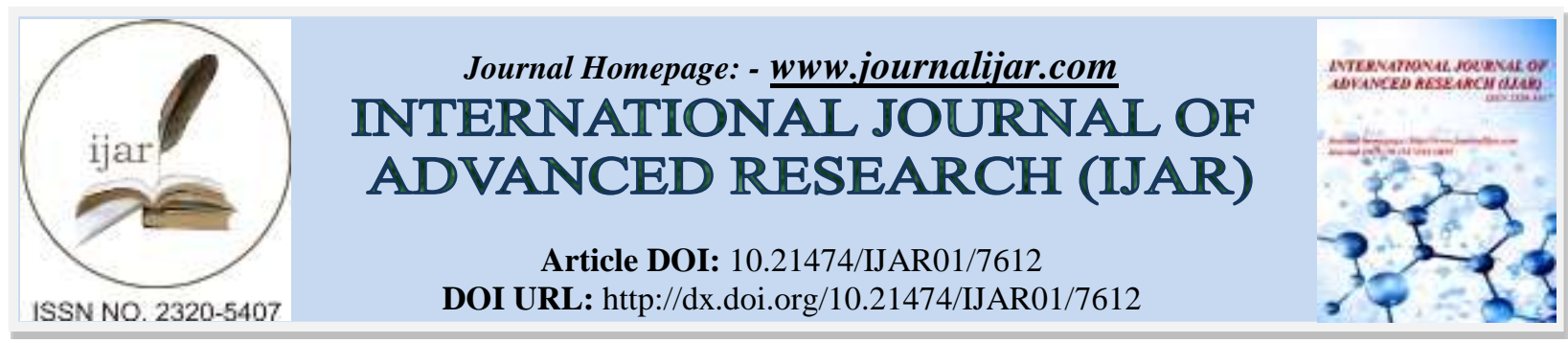

RESEARCH ARTICLE

\title{
THE INFLUENCE OF NATIONAL INSURANCE LEADERSHIP AND UNDERSTANDING OF ARCHIPELAGO INSIGHTS THROUGH STATE DEFENSE AWARENESS.
}

1. Master student of brawijaya university.

Parawita Agus Setyaningtyas $^{1}$, Setyo Widagdo ${ }^{2}$ and Roedi Sulistyono ${ }^{3}$.

2. Law faculty lecturer of brawijaya university.

3. Agriculture faculty lecturer of brawijaya university.

\section{Manuscript Info}

Manuscript History

Received: 22 June 2018

Final Accepted: 24 July 2018

Published: August 2018

\begin{abstract}
The research objectives are as follows: to determine the influence of nationally minded leadership (X1) on awareness of defense of the state, to determine the influence of archipelagic insight (X2) on awareness of defense of the country, to determine the influence of nationalistic leadership and archipelago insight on state defense awareness. This research was conducted at Brawijaya Military Command Headquarters V, while the research time was carried out for 1 month at April 2018.

This research uses descriptive method with quantitative approach. This method was chosen to obtain a clear and detailed picture related to the research problems and phenomena studied. The sampling technique used in this research was random sampling technique because the sample taken was 84 members of Brawijaya Headquarters Management. Data collection techniques used questionnaires, documentation, and interviews. This study uses descriptive statistical techniques.

The results showed that: Based on the $t$ test it was known that nationally minded leadership and insight into the archipelago had a significant influence on the awareness of the defense of National Army Member at Brawijaya Military Command Headquarters, as well as the results of $\mathrm{F}$ test found that nationally minded leadership and insight into the archipelago had an simultaneous influence on state defense awareness of the National Army Member at Brawijaya Military Command Headquarters.
\end{abstract}

Copy Right, IJAR, 2018,. All rights reserved.

\section{Introduction:-}

\section{Background:-}

The world is developing rapidly, the era of globalization and modernization which is marked by the development of science and technology continues to so fast. This can be a challenge for a country, including Indonesia. The challenges and changes of globalization, which are characterized by the advancement of information technology, multimedia, transportation, regionalization, so that the world has become without borders, allowing various layers of society to have access to information technology and. This can threaten slowly but surely the loss of a country's identity, if its people do not have an awareness of their own national insight. 
While on the other hand, the condition of Indonesia's state institutions is now facing a situation of demands for change that is quite significant and intense in various aspects, ranging from the education, economic, social, political systems and even movements that touch the foundations of the state began to surface. Just like the Khilafah movement which has been propagated by various groups of people who assess it as a system that can be a solution to the problems faced by Indonesia.

In this kind of condition, Indonesia must really prepare itself to face all situations and possibilities, whether the data is from outside or the potential for upheaval that occurs from within if it does not want to lose its identity as a nation and state. So the concept of strengthening awareness of defending the country is one viable solution that must be echoed back to the community to strengthen our plural and multicultural state commitment.

The efforts to state defense must be carried out within the framework of developing awareness of defending the country as an effort to realize Indonesian citizens who understand and appreciate and are confident in fulfilling their rights and obligations. Indonesian people also want to have a superior and noble civilization. Such civilization can be achieved if our society and nation are also good society and nation, peaceful, just and prosperous, as has been mandated by the founding fathers in the Preamble of the 1945 Constitution.

The process of cultivating national and archipelago insight into the Indonesian people would not run effectively and efficiently without starting with the government apparatus at Indonesia. That is why nationality-oriented and archipelago-oriented leadership finds its urgency in the context of maintaining the country's identity and sovereignty.

Responding to such situations and conditions, there needs to be serious attention from the government to improve national insight for all components of Indonesian society in the framework of the unity of the Indonesian people. Therefore, the government through the Ministry of Home Affairs passed the Minister of Home Affairs Regulation No. 71 of 2012 concerning National Insight Education Guidelines (PPWK). This regulation is done so that it can be used as a strong, firm, detailed and binding legal protrction to enhance national insight on all components of Indonesian society.

Awareness of state defense must grow in the hearts of all Indonesian people, especially in the National army members. The challenge in maintaining the Unitary State of the Republic of Indonesia from outside and within the country is increasingly complex so that it requires mentality and strength from within the TNI members. Members of the TNI as the front guard in defending the country need to continue to maintain and increase awareness of defending the country.

Members of the National Army Brawijaya Military Command Headquarters is one of the pillars of the TNI that also must be prepared to defend the country if at any time the country is under threat from outside attacks. Awareness of defense of the National Army member country itself is certainly influenced by the leadership within the TNI. The insight of TNI members towards the state is also directly related to the leadership in the body of the TNI, especially in the National Army Brawijaya Military Command Headquarters.

Thus, it can be stated that awareness of defending the country in the body of the National Army must continue to be cultivated through a pattern of coaching. The leadership role in the National Army is the key to raising awareness of defense of the country. Therefore, the National Army needs to develop the right leadership that can mobilize all elements of the TNI in defending the country. One of the leadership is nationalistic leadership.

\section{Research purposes:-}

Based on the above background, the research objectives are as follows;

1. To find out the influence of nationally minded leadership (X1) on state defense awareness.

2. To find out the influence of archipelago insight (X2) on awareness of defense of the country.

3. To find out the influence of nationally minded leadership and archipelago insights on awareness of defense of the country.

\section{Research Methods:-}

Time and Location of Research:-

This research was conducted in Brawijaya Military Command Headquarters and the time of the research was conducted for 1 month, at April 2017 


\section{Research methods:-}

This study uses descriptive method with a quantitative approach or called descriptive statistics. In this study the researcher would like to describe the data about the influence of Nationalism Leadership and Understanding of the Archipelago's Insight on State Defense Awareness.

\section{Sampling technique:-}

The sampling technique used in this study is a random sampling technique because the sample taken is sampling because the sample taken is a member of Brawijaya Military Command Headquarters.

\section{Data Retrieval Techniques:-}

Data collection techniques used in this study were questionnaires, documentation and interviews.

Data analysis technique:-

This study uses qualitative statistical techniques while to analyze using qualitative analysis and quantitative analysis.

\section{Research Result And Discussion:-}

Data Analysis:-

a. Validity Test

The validity test aims to determine whether the instrument has validity. Based on the results of the test, all the questions submitted to the respondent are valid, which has a correlation value from the correlation probability value Sig. (2-tailed) <from a significant level (a) of 0.05 .

Table 1:- Nationality-Based Leadership Validity (X1)

\begin{tabular}{|l|l|l|l|}
\hline Indicators & $\begin{array}{l}\text { Correlation Value } \\
\text { (Pearson Coreclation) }\end{array}$ & Correlation probability Sig. (2-tailed) & Result \\
\hline X1.1 & 0,588 & 0,000 & Valid \\
\hline X1.2 & 0,567 & 0,000 & Valid \\
\hline X1.3 & 0,538 & 0,000 & Valid \\
\hline X1.4 & 0,312 & 0,004 & Valid \\
\hline
\end{tabular}

Source: SPSS calculation

Thus all statements regarding the National Insight Leadership variable can be declared valid.

Table 2:- Validity of Variations in Understanding the Archipelago Insights (X2)

\begin{tabular}{|l|l|l|l|}
\hline Indicators & $\begin{array}{l}\text { Correlation Value } \\
\text { (Pearson Coreclation) }\end{array}$ & Correlation probability Sig. (2-tailed) & Result \\
\hline X2.1 & 0,582 & 0,000 & Valid \\
\hline X2.2 & 0,812 & 0,000 & Valid \\
\hline X2.3 & 0,716 & 0,000 & Valid \\
\hline X2.4 & 0,701 & 0,000 & Valid \\
\hline X2.5 & 0,558 & 0,000 & Valid \\
\hline
\end{tabular}

Source: SPSS calculation

Thus all statements regarding the Archipelago Insights Understanding variable can be declared valid.

Table 3:- State Defense Awareness Variables (Y)

\begin{tabular}{|l|l|l|l|}
\hline Indicators & $\begin{array}{l}\text { Correlation Value } \\
\text { (Pearson Coreclation) }\end{array}$ & $\begin{array}{c}\text { Correlation probability Sig. (2- } \\
\text { tailed) }\end{array}$ & Result \\
\hline Y1 & 0,688 & 0,000 & Valid \\
\hline Y2 & 0,797 & 0,000 & Valid \\
\hline Y3 & 0,684 & 0,000 & Valid \\
\hline Y4 & 0,730 & 0,000 & Valid \\
\hline
\end{tabular}

Source: SPSS calculation

Therefore, all statements regarding the State Martial Awareness variable can be declared valid. 


\subsubsection{Reliability Test}

The reliable test in this study can be seen from the value of Cronbach's Alpha generated from calculations through the help of SPSS 20.0 program. if the statement in the questionnaire has Cronbach's Alpha value>0.6, then the statement is said to be reliable. The following are the results of calculations made by the researcher.

Table 4:- Variable Reliability

\begin{tabular}{|l|l|l|l|}
\hline Variable & Cronbach's Alpha & $\mathrm{N}$ of Items & Result \\
\hline Nationalism Leadership & 0,605 & 8 & Reliable \\
\hline $\begin{array}{l}\text { Understanding of the Archipelago's } \\
\text { Insights }\end{array}$ & 0,768 & 10 & Reliable \\
\hline State Defense Awareness & 0,785 & 8 & Reliable \\
\hline
\end{tabular}

Source: SPSS calculation

Table 4 shows that:

a. Cronbach's Alpha value of nationality >> leadership variable of 0.6 , then the statement was declared reliable.

b. Nusantara insight insight variable also obtained Cronbach's Alpha value> 0.6, so this makes the statement contained in the questionnaire said to be reliable.

c. In the dependent variable (Y), namely awareness of defending the country is obtained by the Cronbach's Alpha value is also greater than 0.6 , then the statement is also said to be reliable.

These results indicate that this study can be continued in the next test.

\subsection{Hypothesis Test}

Based on the results of hypothesis testing in this study it can be seen the influence of each variable in this study.

\section{a. Test $\mathbf{F}$}

The results of the F test (simultaneous), the following results are known:

Table 5:- F test (simultaneous)

\begin{tabular}{|l|l|l|l|l|l|}
\hline Model & Sum of Squares & df & Mean Square & F & Sig. \\
\hline Regression & 59,756 & 2 & 29,878 & 67,596 &, $000^{\mathrm{b}}$ \\
\hline Residual & 35,803 & 81 &, 442 & & \\
\hline Total & 95,560 & 83 & & & \\
\hline
\end{tabular}

Source: SPSS calculation

The result of the $F$ value is 67.596 with a significance level of 0.000 , meaning that the Ho hypothesis is rejected and the Ha hypothesis is accepted. This means that there is a significant influence between Nationality Leadership Leadership (X1), Archipelago Insight (X2), together (simultaneously) on State Defense Awareness (Y).

\section{b. T test}

The results of the $t$ test obtained obtained the results presented in the table as follows:

Table 6:- T test (partial)

\begin{tabular}{|l|l|l|}
\hline Model & t-count & Sig. \\
\hline (Constant) & 1,405 & 0,164 \\
\hline Nationalism Leadership & 2,693 & 0,009 \\
\hline Archipelago Insight & 9,637 & 0,000 \\
\hline
\end{tabular}

Source: SPSS calculation

Based on table 6 , shows that:

a. The significance value of the National Insight Leadership variable (X1) obtained a significance value of 0.009. This shows that there is a rejection of Ho's hypothesis and acceptance of Ha's hypothesis which means that there is a significant influence of Nationality Leadership on national defense awareness (Y).

b. The significance value of the Archipelago Insight Understanding variable is 0,000 . This means that the significance value of the Archipelago Insight Understanding variable (X2) $<0.05$. This shows that there is a rejection of Ho's hypothesis and acceptance of Ha's hypothesis, which means that there is a significant influence from the Archipelago Insight Understanding variable on the awareness of state defense (Y).

c. For the understanding variable of archipelago insight (X2) obtained a significance value of 0,000 . This shows that there is a rejection of the Ho hypothesis and acceptance of the Ha hypothesis which means there is a 
significant influence from the understanding of the archipelago's insight on the awareness of defense of the country (Y).

c. $\mathbf{R} 2$ test (R-squared)

Table 7:- R2 test (R-squared)

\begin{tabular}{|c|c|c|c|c|}
\hline \multicolumn{5}{|c|}{ Model Summary $^{b}$} \\
\hline Model & $\mathrm{R}$ & R Square & Adjusted R Square & Std. Error of the Estimate \\
\hline 1 &, $791^{\mathrm{a}}$ & ,625 & ,616 & 665 \\
\hline
\end{tabular}

Source: SPSS calculation

Based on table 4.15 it is known that the value of $\mathrm{R} 2$ is 0.625 . This shows that the variation of nationalistic leadership (X1), and understanding of the archipelago (X2), can explain the state defense awareness variable (Y) by $62.5 \%$, and the remaining $37.5 \%$ is explained by other variables outside the model.

\section{Discussion:-}

The discussion in this study is based on the results of testing the hypothesis of the $\mathrm{F}$ test and test which was analyzed using multiple linear regression models, because the results of testing the hypothesis of the $F$ test and test can be used to draw conclusions obtained after conducting research.

Variable Leadership with Nationality Concept (X1), Partially Affecting the Awareness of Members of the National Army Membership at the Headquarters of Brawijaya Military Command V.

Nationalistic leadership is an activity to achieve a common goal by having the same perspective in understanding its identity as a nation that upholds the values of unity and unity. In this study the nationalistic leadership variable (X1) has a significance level of 0.009 whose value is smaller than 0.050 or $5 \%$, so it can be stated that nationally minded leadership has proven to have a significant influence on state defense awareness of TNI Agencies in the Barawijaya Headquarters of Military Command V.

The results above show that good and strong nationalistic leadership can encourage members of the TNI to have the awareness of defending the country so as to encourage the achievement of TNI members' readiness to defend the country in various situations. The results of this study are also in accordance with the theory put forward by Narwati (2011) that a leader who has national insight reflected in the way of thinking, acting and being insightful that places the interests of the nation and state above their self and group interests, using Indonesian, appreciates differences among friends, and maintaining the nation's culture will inspire subordinates to have awareness in defending the country.

National-minded leadership will arouse awareness of TNI members to love the homeland, carry out all obligations of TNI members, have Pancasila ideology, and be willing to sacrifice for the benefit of the nation and state. The existence of nationality-oriented leadership will make National Army members ready to carry out state duties.

Variable Understanding of Archipelagic Insights (X2) Partially Affecting the Awareness of the Member States of the National Army Membership at the Headquarters of Brawijaya Military Command V.

Understanding of the archipelago insight is an activity to achieve a common goal by having the same perspective in understanding its identity as a nation that upholds the values of unity and unity. In this study the Archipelago Insight Understanding variable (X2) has a significance level of 0,000 whose value is smaller than 0.050 or $5 \%$, so that it can be stated that the Understanding of the Archipelago Insights is proven to have a significant influence on the awareness of defense of the national army membership at the headquarters of brawijaya military command V.

The results above show that a good and strong understanding of the archipelago can encourage National Army members to have the awareness of defending the country so as to encourage the achievement of TNI members' readiness to defend the country in various situations. The results of this study are in accordance with the theory that the archipelago's insight plays a role in guiding the Indonesian nation in the implementation of its life and as a sign in the struggle to fill its independence. (Sutarman, 2011:83) 
Through understanding the archipelago, members of the TNI will be directed to prioritize national interests rather than self and group interests. The insight of the archipelago will encourage TNI Members to have awareness in defending the country.

Nationality-Based Leadership (X1), and Archipelago Understanding Insights (X2) Simultaneously Affecting the Awareness of the Defense of Members of the National Army Membership at the Headquarters of Brawijaya Military Command V

Referring to the results of multiple linear regression analysis, it is known that the regression coefficient value of each independent variable has a positive sign. The result of the hypothesis testing of the $\mathrm{F}$ test shows a significance level of 0,000 which is smaller than 0.05 or $5 \%$. This shows a unidirectional relationship between nationalistic leadership (X1), archipelago insight (X2) and state defense (Y) awareness. R2 (R-squared) value of 62.5\% shows a strong relationship of changes in awareness variables of twelve countries that are influenced by two variables, namely nationality (X1), insight into the archipelago (X2), while the remaining $37.5 \%$ is influenced by other variables outside the variables used in this study.

From the results of the $\mathrm{F}$ test, it is known that the independent variable has a significant effect simultaneously (simultaneously) on the awareness of defending the country. This shows that nationality (X1), Archipelago's insight understanding (X2) gives significant simultaneous influence on state defense awareness. This is in accordance with the theory put forward by Sutarman that awareness of defending the country in the form of national and state awareness, obedience, obedience to laws and democratic rules, love of the homeland, through sincere service to society, and active in advancing the nation and state can be embedded if you have an understanding of the archipelago's insight and given examples or examples of leaders who develop nationalistic leadership.

Based on the results of the interview with National Army Membership at the Headquarters of Brawijaya Military Command V, it can be seen that the awareness of defending National Army Membership at the Headquarters of Brawijaya Military Command V is very high. This is inseparable from national-minded leadership practices that exist in the Headquarters of Brawijaya Military Command environment, such as not differentiating religious tribes, and members of the National Army, respecting the culture and customs of each member of the TNI, and maintaining Unity in Diversity.

The Headquarters of Brawijaya Military Command also runs a strategy to increase understanding among other subjects 1) the main socialization is to maintain the preservation of national culture, 2) provide information through Brawijaya magazine about the insight of the archipelago, 3) appoint a member of the members to become a cadre of trainers about the insight of the archipelago.

\section{Conclusions and Suggestions:-}

\section{Conclusions:-}

Based on the results of the tests that have been carried out, this research can be concluded as follows:

1. Based on the $t$ test, it is known that nationally minded leadership has a significant influence on the awareness of National Army state defending at the Headquarters of Brawijaya Military Command.

2. Based on the t test, it is known that the understanding of the archipelago insight proved to have a significant effect on the awareness of the defense of the members of the National Army.

3. In accordance with the results of the F test, it can be seen that nationally minded leadership and understanding of the archipelago's insight have an simultaneous effect on the awareness of the defense of a member of the National Army.

\section{Suggestion:-}

Based on the conclusions described above, the suggestions that can be submitted in this study are as follows:

1. Considering the nationally minded leadership and understanding of the archipelago insight is a significant variable influencing awareness of defense of member states of the National Army at the Headquarters of Brawijaya Military Command V, then the Headquarters of Brawijaya Military Command V needs to maintain and improve nationally minded leadership and insight into the archipelago that has gone well so the Headquarters of Brawijaya Military Command V has members who are always ready to defend the country.

2. To improve nationalistic leadership and understanding of the archipelago, the Headquarters of Brawijaya Military Command V needs to conduct nationality-oriented training and education. 
3. For further researchers who want to do research with the same theme, it is recommended to use variables other than those contained in this study.

\section{Bibliography:-}

1. Arikunto, Suharsimi. 2013. Prosedur Penelitian Suatu Pendekatan Praktik. Jakarta; Rineka Cipta.

2. Astawa, Dewa Nyoman Wija. 2011. Pola Pikir Meningkatkan Wawasan Kebangsaan Mencegah Disintegrasi Bangsa. Surabaya: Paramita

3. Danim, Sudarmawan. 2004. Motifasi Kepemimpinan \& Efektifitas Kelompok. Jakarta : PT Renika Cipta

4. Kusmayadi, Yadi, 2017, Hubungan Antara Pemahaman Sejarah Nasional Indonesia dan Wawasan Kebangsaan Dengan Karakter Mahasiswa (Studi Pada Mahasiswa Pendidikan Sejarah FKIP Universitas Galuh Ciamis). Jurnal AGASTYA Volume. 7 Nomor. 2, JULI.

5. Lubis, Darwin Parlaungan. Mbina Pinem. \& M. Ridha S. Damanik, 2017, Peran Pendidikan Geografi Dalam Membangun Wawasan Kebangsaan. Prosiding Seminar Nasional Tahunan Fakultas Ilmu Sosial Universitas Negeri Medan Tahun 2017 Vol. 1 No. 1 2017, Hal. 66-72

6. Margono. 2010. Metodologi Penelitian Pendidikan. Jakarta: Rineka Cipta,

7. Sugiyono, 2013, Metode Penelitian Pendidikan : Pendekatan Kuantitatif, Kualitatif, dan $R \&$ D . Bandung : Alfabeta.

8. Suhady, Idup dan A.M. Sinaga. 2006. Wawasan Kebangsaan dalam Kerangka Negara Kesatuan Republik Indonesia. Jakarta: Lembaga Administrasi Negara Republik Indonesia.

9. Umar, Husein. 2011. Metodologi Penelitian. Jakarta: Gramedia Pustaka Umum. 